Sains Malaysiana 49(8)(2020): 2013-2022

http://dx.doi.org/10.17576/jsm-2020-4908-24

\title{
Comparing and Forecasting using Stochastic Mortality Models: A Monte Carlo Simulation
}

(Perbandingan dan Peramalan menggunakan Model Kematian Stokastik: Suatu Simulasi Monte Carlo)

\author{
ZAMIRA HASANAH ZAMZURI* \& GWEE JiA HUI
}

\begin{abstract}
Generalized Age-Period-Cohort Model (GAPC) has been widely accepted as a mean of modelling mortality improvement but the parameter risk associated with it raises problem on forecasting accuracy. Hence, this study aims to utilise the simulation strategy to account for variability and uncertainty in the point and interval mortality estimate by using mortality experience of Taiwan. This study also aim to identify the best mortality model for Taiwan data and further compute the ruin probability to assess the solvency risk. The results show that the error of point estimate could be minimized using simulation depending on the type of forecast statistics and models. The interval estimates on the other hand generally produce similar width in most cases as compared to those without using simulation, suggesting that simulation failed to increase forecast accuracy significantly in terms of interval estimate with exception on Haberman-Renshaw model with cohort effect in squared form (HRb) in high age female population projection. AgePeriod-Cohort (APC) model is found to be most suited to both gender population in Taiwan by focusing on its ability to generate biological plausible rate, goodness of fit and forecasting performance. The mortality forecast based on APC model is then used in virtual cash flow projection on an annuity portfolio. Result shows that Renshaw-Haberman (RH) model is more sensible in annuity pricing as its product produce least solvency risk besides showing that the risk is greatly contributed by women population of higher age in the case of Taiwan.
\end{abstract}

Keywords: Generalized Age-Period-Cohort Model; parameter uncertainty; simulation; solvency risk

\section{ABSTRAK}

Model Umur-Tempoh-Kohot Teritlak (GAPC) telah luas digunakan untuk memodelkan penambahbaikan kematian tetapi wujud risiko ketidaktentuan parameter terhadap hasil unjuran model tersebut. Oleh yang demikian, kajian ini bermatlamat untuk mengaplikasikan konsep simulasi dengan mengambil kira kepelbagaian dan ketidakpastian dalam anggaran titik dan selang bagi data Taiwan. Kajian ini juga bertujuan untuk mengenal pasti model kematian terbaik untuk data Taiwan seterusnya menghitung kebarangkalian kemusnahan untuk menilai risiko kesolvenan. Hasil kajian menunjukkan bahawa kaedah simulasi Monte Carlo berupaya meminimumkan lagi ralat pelunjuran untuk statistik dan model tertentu pada anggaran titiknya. Namun, kebanyakan selang hasilnya pula adalah lebih kurang sama dengan hasil tanpa simulasi, maka tidak memberi anggaran selang yang terbukti lebih jitu untuk kebanyakan kes kecuali model Haberman-Renshaw dengan kesan kohort dalam bentuk kuasa dua (HRb) pada populasi wanita berumur tinggi. Model APC (Age-Period-Cohort) sesuai untuk melunjurkan kematian masa depan populasi lelaki dan perempuan di Taiwan dengan tumpuan terhadap keupayaannya menghasilkan unjuran yang munasabah dari segi biologi, kebagusan penyuaian serta prestasi pelunjuran. Pelunjuran pengaliran kewangan portfolio anuiti menunjukkan bahawa portfolio yang ditentuharga oleh model Renshaw-Haberman (RH) mengundang risiko kesolvenan yang paling rendah dan populasi wanita berumur tua memberi sumbangan terbesar terhadap risiko ini dalam kes Taiwan.

Kata kunci: Ketidaktentuan parameter; Model Umur-Tempoh-Kohot Teritlak; risiko kesolvenan; simulasi

\section{INTRODUCTION}

Mortality improvement is a phenomenon whereby a person is expected to live longer than previous year at the same age basis (Nor et al. 2018). This is proven to be observed in many areas such as Europe, Oceania, America, Asia, Soviet Union, and Africa since 1950. However, the improvement impacts insurers and government sectors which provide pension fund the most because the underlying policies may experience higher payout than expected. This leads to longevity risk in which the premium collected at the policy issue date may not be sufficient to cover up future obligated payments. According to Dushi et al. (2010), ignorant on mortality 
improvement has underestimated the pension liability by $12 \%$ for male participant in Defined-Benefit Pension Plan in United States. Focusing on Taiwan, increasing reliance on life annuity products follow by Labour Pension Act enforcement even increases the insurance companies' exposure towards solvency risk. Hence, a better approach is by accounting such improvement in valuation and pricing procedure based on reliable mortality projection to ensure sustainablity of portfolio.

In this paper, the focus is to project such mortality by using stochastic mortality models in age-periodcohort framework. Generally, it comprises of four main components according to Villegas et al. (2015): the number of death that is distributed randomly as either Poisson or binomial, a predictor structure, a link function and a set of parameter contraints. The link function is either $\ln m(x, t)$ referring to the log of the mortality rate or logit $q(x, t)$ referring to the logit of the probability of death, depending on whether the random component is Poisson or binomial distributed, respectively. Through fitting process, four important parameters are obtained: an age-static parameter $\left(\alpha_{x}\right)$, period index $\left(K_{t}\right)$, cohort index $\left(Y_{t-x}\right)$ and age modulating term $\left(\beta_{x}^{(i)}, i=0,1,2 \ldots\right)$. The dynamic process that drive the mortality changes depends on the changes in period index and cohort index which Box-Jenkins methodology is suitable in projection of both indices into the future. Some examples of GAPC model include model proposed by Cairns et al. (2006), Lee and Carter (1992), and Renshaw and Haberman (2006) will be discussed in details in the next section.

Several papers in literature aim to compare the performance of the existing stochastic moratlity models. Cairns et al. (2009) found that the Cairns-Blake-Down (CBD) model fits the best for England and Wales male data set while Renshaw-Haberman (RH) is the best for U.S male data. Yang et al. (2010) found that a model with an age shift performs the best compared to Lee-Carter (LC), Renshaw-Haberman (RH) and Cairns-Blake-Dowd (CBD) models. Haberman and Renshaw (2011) conduct detail comparisons on the mortality models for England and Wales data. Most of the previous work in mortality model comparisons only focus on two to three models, there are limited number of papers that compared and summarized multiple mortality models suggested in the literature. Therefore, this paper provides more insight in terms of the suggested models in the literature and also account for variation and uncertainty elements by conducting the simulation study.

From the literature, we can deduce that no one model fits all and it depends on the characteristics of the data. Different best models may identified for different contries, genders or ages. However, there exist several uncertainties in such model that are not included in standard mean of projection such as parameter uncertainty and the choice of underlying ARIMA models, making the projection less reflecting possible mortality experience. Besides, interval estimate generally provide more information than a point estimate, however due to the existence of bilinear term in most models, making the formulation of standard deviation of mortality estimate nearly impossible. Hence, the objective of this paper was to conduct the simulation study in order to account for variablity and uncertainty in the model's parameter estimates. In addition, this paper also focus on determining the best model describing and projecting mortality of different gender population, followed by a long term project to investigate future mortality development of both gender in the long future. Lastly, provided with suitable GAPC model describing future mortality experience, it is important to quantify risk associated with mortality-linked products that are priced under other GAPC mortality projection.

\section{MATERIALS AND METHODS}

\section{DATA AND ASSUMPTIONS}

Several important assumptions made throughout this paper. First, the number of deaths is assumed to follow Poisson distribution. Secondly, the force of mortality is assumed to be constant between integral ages and years. In accordance to this assumption, probability of death, $q(x, t)$ and mortality rate. $m(x, t)$ are related together as shown in (1).

$$
q(x, t)=1-e^{-m(x, t)}
$$

Next, the death count is assumed to be independently distributed for each age and year. Two types of raw data are used: the number of death in each age and year, $D(x, t)$ as well as their respective exposure to death, $E(x, t)$ of Taiwan population according gender from year 1970 to 2014 which can be obtained from Human Mortality Database (HMD). Due to the Poisson assumption on death count, all stochastic mortality models have $\ln m(x, t)$ as their link function in which $m(x, t)$ represents the central crude death rate of someone age $x$ in year $t$ which can be transformed by dividing $D(x, t)$ by $E(x, t)$.

In this paper, only observations ranging from age 55 to 89 were considered. The data is then partitioned into two sets, the training data consists of observations from 1970 to 2000, while testing data is from 2001 to 2014 .

\section{OVERVIEW ON STOCHASTIC MORTALITY MODELS}

Lee and Carter (1992) proposed a stochastic model with simple structure that includes only an additive age-static $\alpha_{x}$ and a bilinear term: $\ln m(x, t)=\alpha_{x}+\beta_{x} K_{t}+\varepsilon_{x, t}$, imposing the following constraints $\sum_{x} \beta_{x}=1$ and $\sum_{t} \kappa_{t}=0$ to ensure the identification of parameters. The model assumed Gaussian error structure which raises issues on later research mainly because of its homoskedaticity which is unrealistic on human mortality behavior. Hence, Brouhns et al. (2002) proposed a Poisson version of LeeCarter model that allow for heteroskedatic error structure across different age groups. The model has predictor structure and parameter constraints similar to classical 
Lee-Carter model, except $D(x, t)$ is assumed to be Poisson distributed. However, such models ignore potential cohort effect that proved to exist in England population, hence Renshaw and Haberman (2006) try to incorporate such effect in forecasting. It is structured as $\ln m(x, t)=\alpha_{x}+\beta_{x}^{(1)}$ $K_{t}+\beta_{x}^{(0)} \gamma_{t-x}$ with additional contraints $\sum_{x} \beta_{x}(0)=1$ and $\sum_{c=t_{1}-x_{k}}^{t_{n}-x_{1}} \gamma_{c}=0$. In both cases, mortality projection is done by treating period index and cohort index as time series data and project them using classical BoxJenkins methodology. They also introduces the special case of Renshaw and Haberman model is by assuming cohort modulating term to be equal to 1 across ages. Hence, the bilinear term do not appear in this model and have predictor structure $\ln m(x, t)=\alpha_{x}+K_{t}+\gamma_{t-x}$. An additional parameter constraint $\sum_{c=t_{1}-x_{k}}^{t_{n}-x_{1}} c \gamma_{c}=0$ is required for fully indentification.

The model discussed here all assume death count to be Poisson distributed and an age-static parameter is required. However, when turning into mortality-linked securities pricing context, capturing mortality dynamic is upmost importance. Hence, the study of Cairns et al. (2006) introduces two period indices and eliminates the age-static term. Also, the death count is assumed to be binomially distributed instead of Poisson. The structure is logit $\left.q(x, t)=K_{t}^{(1)}+x-x\right) K_{t}^{(2)}$ with no parameter contraints needed. Cohort effect is then incorporated in similar model by Haberman and Renshaw (2011) in two different forms, which is logit $q(x, t)=K t(1)$ $+(x-x) K_{t}^{(2)}+Y_{t-x}$ and logit $\left.q(x, t)=K_{t}^{(1)}+x-x\right) K_{t}^{(2)}+$ $\left[(x-\bar{x})^{2}-\hat{\sigma}^{2}\right] \kappa_{t}^{(3)}+\gamma_{t-x}$, commonly known as HRa and $\mathrm{HRb}$ model, respectively. The parameter constraints involve $\sum_{c=t_{1}-x_{k}}^{t_{n}-x_{1}} \gamma_{c}=0$ and $\sum_{c=t_{1}-x_{k}}^{t_{n}-x_{1}} c \gamma_{c}=0$ for both models, with additional $\sum_{c=t_{1}-x_{k}}^{t_{n}-x_{1}} c^{2} \gamma_{c}=0$ for $\mathrm{HRb}$ model. Even though there are many GAPC models proposed until now, they share common features in terms of predictor structures, fitting and projecting algorithm. Generally, fitting process can be done using maximum likelihood while mortality projection could be done by extending all period and cohort indices using time series methodology.

Based on the discussions, six models will be compared as shown in Table 1. However, due to the difference in nature of original link function, this paper adopts $\ln m(x, t)$ as standardization corresponding to Poisson assumption on death count. Table 1 summarizes the six models studied in this paper.

TABLE 1. The structure of GAPC models

\begin{tabular}{|c|c|c|}
\hline Models & Brief description & Predictor Structure \\
\hline Lee Carter (LC) & $\begin{array}{l}\text { includes only an additive age-static } \alpha_{x} \text { and a bilinear } \\
\text { term }\end{array}$ & $\ln m(x, t)=\alpha_{x}+\beta_{x} \kappa_{t}$ \\
\hline $\begin{array}{l}\text { Renshaw } \\
\text { Haberman (RH) }\end{array}$ & the Poisson version of the model with cohort effect & $\ln m(x, t)=\alpha_{x}+\beta_{x}^{(1)} \kappa_{t}+\gamma_{t-x}$ \\
\hline $\begin{array}{l}\text { Age Period } \\
\text { Cohort (APC) }\end{array}$ & $\begin{array}{l}\text { the special case of the RH model by assuming cohort } \\
\text { modulating term to be equal to } 1 \text { across ages }\end{array}$ & $\ln m(x, t)=\alpha_{x}+\kappa_{t}+\gamma_{t-x}$ \\
\hline $\begin{array}{l}\text { Cairns Blake } \\
\text { Dowd (CBD) }\end{array}$ & $\begin{array}{l}\text { introduces two period indices and eliminates the age- } \\
\text { static term, the death count is assumed to be binomially } \\
\text { distributed }\end{array}$ & $\ln m(x, t)=\kappa_{t}^{(1)}+\kappa_{t}^{(2)}(x-\bar{x})$ \\
\hline $\begin{array}{l}\text { Haberman- } \\
\text { Renshaw (a) } \\
\text { (HRa) }\end{array}$ & cohort effect included in the CBD model with form (a) & $\ln m(x, t)=\kappa_{t}^{(1)}+\kappa_{t}^{(2)}(x-\bar{x})+\gamma_{t-x}$ \\
\hline $\begin{array}{l}\text { Haberman- } \\
\text { Renshaw (b) } \\
(\mathrm{HRb})\end{array}$ & cohort effect included in the CBD model with form (b) & $\begin{aligned} \ln m(x, t)=\kappa_{t}^{(1)}+ & \kappa_{t}^{(2)}(x-\bar{x}) \\
& +\left[(x-\bar{x})^{2}\right. \\
& \left.-\hat{\sigma}^{2}\right] \kappa_{t}^{(3)}+\gamma_{t-x}\end{aligned}$ \\
\hline
\end{tabular}

\section{SIMULATION}

Simulation studies can be conducted to incorporate various uncertainties (Zamzuri et al. 2018). These uncertainties can be sourced by the parameter as a result of sampling error, or the uncertainty on suitainblility of
ARIMA model in period and cohort indices forecasting as well as the forecast error of ARIMA models. In each simulation, there are two important phases, which are fitting and projecting. These processes are repeated for 5000 times The simulation procedures are: Assume that 
the observed death count at each age and year as the mean of independent Poisson distribution, then draw one sample for each cell corresponding to the age and year. The simulated death count is divided by corresponding number of exposure to obtain the simulated central crude death rate. Fit the six models to the simulated rate data, respectively, using maximum likelihood with aid of gnm package in R. For each period indices, choose the best fitted ARIMA model according to Akaike Information Criterion (AIC), while leaving cohort index fixed at $\operatorname{ARIMA}(1,1,0)$. Simulate sample pathway of each period and cohort indices for 14 years. Transform central crude death rate into probability of death. The process is repeated for 5000 times.

At the end of simulation, there would be 5000 set of mortality forecasts for 14 years ahead spanning across all ages and years. Hence, point estimate of mortality could be taken at any age and year by taking the mean of those 5000 set forecasts. While for the interval estimate, empirical prediction interval could be obtained via 2.5 th percentile and 97.5th percentile for lower and upper limit, respectively.

\section{FITTING AND FORECASTING USING STOCHASTIC MORTALITY MODELS}

Generally, maximum likelihood is used to obtain the parameters. Due to the Poisson assumption on death count, the likelihood equation is

$$
L[d(x, t), \hat{d}(x, t)]=\sum_{x} \sum_{t} w(x, t)[d(x, t) \log \hat{d}(x, t)-\hat{d}(x, t)-\log d(x, t) !]
$$

whereby

$$
\hat{d}(x, t)=E(x, t) g^{-1}\left(\alpha_{x}+\sum_{i=1}^{N} \beta_{x}^{(i)} \kappa_{t}^{(i)}+\beta_{x}^{(0)} \gamma_{t-x}\right)
$$

For RH, APC, HRa, and HRb model which consist of cohort term, cohort with less than 3 observations are weighted zero to avoid overparameterization (Cairns et al. 2009; Haberman \& Renshaw 2011). Fitting process generally produces vectors of parameters $\alpha_{n}=\{\alpha 55$, $\alpha 56, \ldots, \alpha 89\} n, \boldsymbol{\beta}_{n}^{(i)}=\left\{\beta_{55}^{(i)}, \beta_{56}^{(i)}, \ldots \beta_{89}^{(i)}\right\}_{n}, i=0,1,2, \ldots$, $\boldsymbol{\kappa}_{\boldsymbol{n}}^{(i)}=\left\{\kappa_{1970}^{(i)}, \kappa_{1971}^{(i)}, \ldots \kappa_{2000}^{(i)}\right\}_{n}, i=1,2,3 \ldots$ a n d $\gamma_{n}=$ $\left\{\gamma_{1884}, \gamma_{1885}, \ldots, \gamma_{1942}\right\}_{n}$ for each nth simulation. In mortality projection, ARIMA model is used in extending both period and cohort indices into the future in all cases.

$$
\nabla^{d_{i}} \kappa_{t}^{(i)}=\delta_{0}^{(i)}+\phi_{1}^{(i)} \nabla^{d_{i}} \kappa_{t-1}^{(i)}+\ldots+\phi_{p_{i}}^{(i)} \nabla^{d_{i}} \kappa_{t-p_{i}}^{(i)}+a_{t}^{(i)}+\theta_{1}^{(i)} a_{t-1}^{(i)}+\ldots+\theta_{q_{i}}^{(i)} a_{t-q_{i}}^{(i)}
$$

\section{CASH FLOW PROJECTION AND RISK ASSESSMENT}

Cash flow projection is done in order to assess future portfolio liability as a result of using different mortality models in portfolio pricing. This paper assumes a portfolio consists of 10000 temporary life annuitant which enter into system by paying net single premium in year 2019 with periodic payback at the end of subsequent year if annuitant is still alive. Risk is quantified by comparing the discounted future cash flow with premium paid through simulation technique. The procedure is as follows:

Estimate the number of exposure to death in year 2019 $(t=0)$

$$
E(x+t, 2019+t)=-\frac{L(x+t, 2019+t) q(x+t, 2019+t)}{\ln p(x+t, 2019+t)}
$$

Sample one observation on death count which follows the expected value in Step 1. In the case of annuity claim of NT\$ 1 for every annuitant that successfully survives to the next year, the total number of survivors next year equal to amount of liability to be beared this year end.

$D(x+t, 2019+t) \sim$ Poisson $[E(x+t, 2019+t) m(x+t, 2019+t)]$

Process of estimating exposure and sampling death count is repeated for year 2020 onwards until 2044 where in exposure estimation each year, sample death count on previous year is required. $(t=1,2,3, \ldots, 24)$.

Discount generated cash flow with interest rate at $4 \%$ annually back to year 2019 and compared with the net single premium paid computed via:

$$
a_{x: 25}(2019)=\frac{1-A_{x: 15}(2019)-i A_{x: 15}^{1}(2019)}{i}
$$

The cash flow projection process is repeated 5000 times with different sample pathway of probability of death.

At the end of simulation, two important statistics are compared, which is the probability of ruin which measure the percentage whereby future obligations exceed premium received and the amount of severity which measure the deficit if ruin occurred. In this simulation, the probability of ruin is calculated based on a simple formula:

Prob. of ruin $=\frac{\text { No.of simulation }(\text { Obligations }>\text { Premium received })}{\text { Total } \text { number of simulation }} \times 100$

\section{RESULTS AND DISCUSSION}

\section{EFFECTIVENESS OF SIMULATION}

In this study, the data are partitioned into the training and testing sets. For the training data, we used data from 1970 to 2000 whereas the testing data is from 2001 to 2014 . The forecasting period for this study is from year 2015 to 2045. To determine whether inclusion of various source of variations could minimized further forecasting error, projection is done from year 2000 to 2014 using simulation and compared with the true value through three measures: mean absolute percentage error (MAPE), mean absolute deviance (MAD) and mean squared error (MSE). 
Generally, accounting for various risks into forecasting is able to generate more precise estimate as shown by the mark " $\checkmark$ ". The " $\checkmark$ " mark indicates that the measure's value from the simulation study is smaller than the one without simulation. The improvement is significant while projecting $q(x, t)$ using LC, CBD and HRb model for male population. Female population on the other hand shows intense improvement in all model forecast, except on HRa model. However, inclusion on risks do not minimized error on $m(x, t)$ projection in most cases. Here, simulation improves accuracy of point forecast in different scenario whereby it performs well in Taiwanese female population especially in projecting $q(x, t)$. Turning to interval estimate, inclusion on risks generally produces greater width especially in high age population in both genders in all cases. Hence, although simulation produces better point forecast, it does not improve accuracy in interval estimate at significant level. However, there is one special case whereby the high age female population projection using HRb model shows significant improvement after risk inclusion (Tables $2 \& 3$ ).

TABLE 2. The performance of the six models for the mortality rate and probability death of the male population

\begin{tabular}{|c|c|c|c|c|c|c|}
\hline \multirow[t]{2}{*}{ Model } & \multicolumn{3}{|c|}{ Mortality rate, $m(x, t)$} & \multicolumn{3}{|c|}{ Probability of death, $q(x, t)$} \\
\hline & MAPE & MAD & MSE & MAPE & MAD & MSE \\
\hline $\mathrm{LC}$ & $\checkmark$ & & & $\checkmark$ & $\checkmark$ & $\checkmark$ \\
\hline RH & & $\checkmark$ & $\checkmark$ & & & \\
\hline \multicolumn{7}{|l|}{ APC } \\
\hline CBD & & & & $\checkmark$ & $\sqrt{ }$ & $\checkmark$ \\
\hline HRa & & $\checkmark$ & $\checkmark$ & & & \\
\hline $\mathrm{HRb}$ & & $\checkmark$ & $\checkmark$ & $\checkmark$ & $\checkmark$ & $\checkmark$ \\
\hline
\end{tabular}

TABLE 3. The performance of the six models for the mortality rate and probability death of the male population

\begin{tabular}{|c|c|c|c|c|c|c|}
\hline \multirow[t]{2}{*}{ Model } & \multicolumn{3}{|c|}{ Mortality rate, $m(x, t)$} & \multicolumn{3}{|c|}{ Probability of death, $q(x, t)$} \\
\hline & MAPE & MAD & MSE & MAPE & MAD & MSE \\
\hline LC & & & & $\checkmark$ & $\checkmark$ & $\checkmark$ \\
\hline RH & $\checkmark$ & $\checkmark$ & $\checkmark$ & $\checkmark$ & $\checkmark$ & $\checkmark$ \\
\hline APC & & & & $\checkmark$ & $\checkmark$ & $\checkmark$ \\
\hline CBD & & & & $\checkmark$ & $\checkmark$ & $\checkmark$ \\
\hline HRa & & & & & & $\checkmark$ \\
\hline $\mathrm{HRb}$ & & $\checkmark$ & $\checkmark$ & $\checkmark$ & $\checkmark$ & $\checkmark$ \\
\hline
\end{tabular}

\section{BEST MORTALITY MODELS DESCRIBING TAIWANESE POPULATION}

In determining the best mortality model for the Taiwanese data, several criterias should be accounted for which include parsimony, transparency, ability to generate sample paths, incorporation of cohort effect, and ability to produce nontrivial correlation structure (Cairns et al.
2009). Other desire qualities include robustness, able to generate biological resonable forecast and good fit to historical data. However, this study will only focus on ability to generate biological plausible forecast, goodness of fit and forecasting performance due to limitation in assessing other qualities using simulation. Based on Figure 1, for the first criteria, it can be noted 
that all models are able to generate interval forecast which reasonable along with age development, i.e. the interval widths for younger age population are always smaller than the older age in all models, which implies that its possible mortality pathways are always below the older population. However, in male population, curvature is observed in high age population in RH and HRa model forecast while all age group for M7 model. In female population, curvature is obvious on HRb model forecast only while the other models are able to generate steadily decreasing rate.
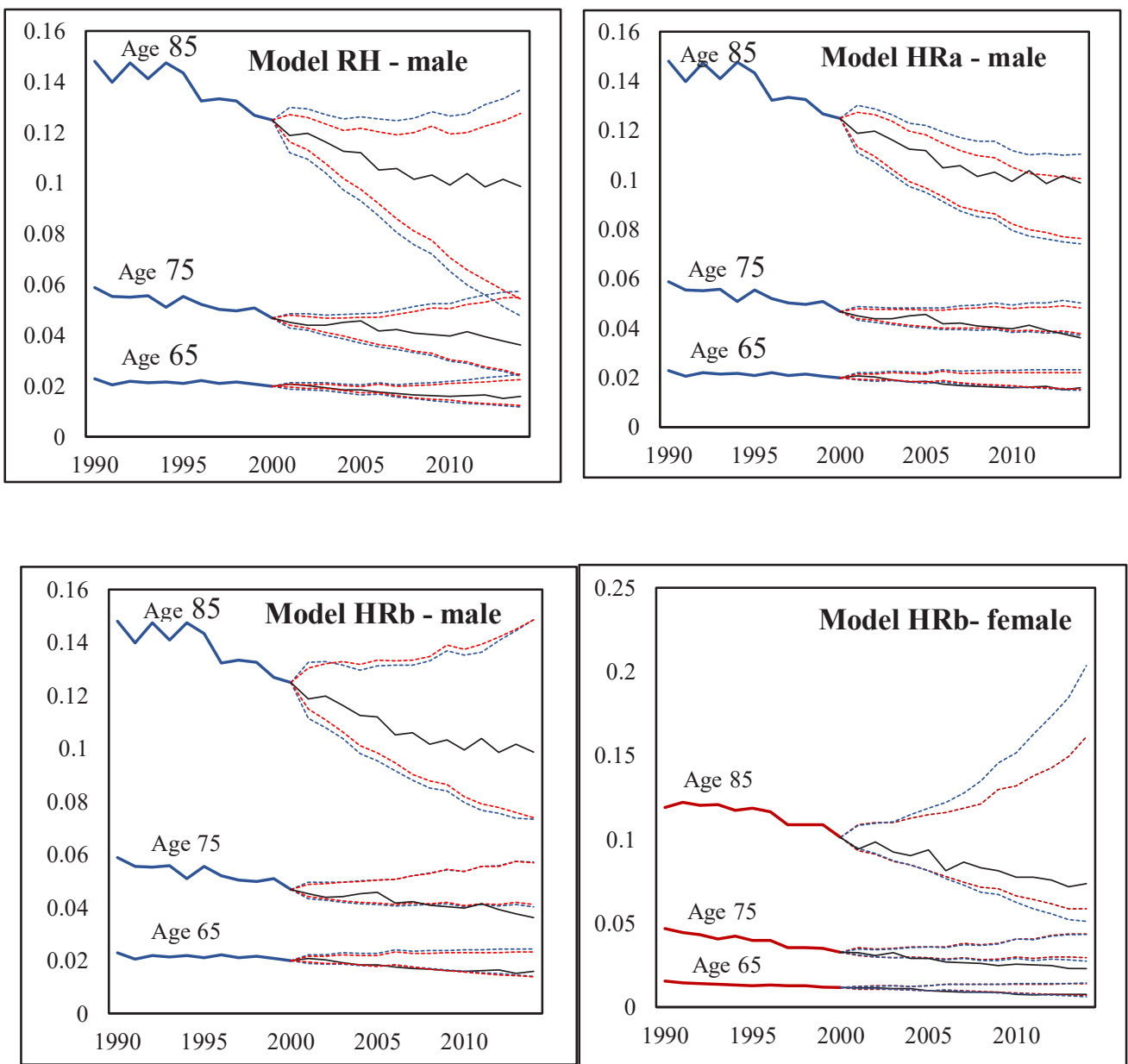

FIGURE 1. Forecasted values for models RH, HRa and $\mathrm{HRb}$ for the male population and $\mathrm{HRb}$ for the female population

For the next criteria, AIC and BIC are used to determine the goodness of fit whereby the smaller the measure, the better the model fits into historical data. As both measures have different value in each simulation due to changing fitting data set, hence, mean of their value is taken as comparing basis. Focusing on male population, AIC and BIC both showing inconsistent result among each other. RH model is best model chosen by AIC with mean value of 11742.15 while HRa model is chosen by BIC with value of 12460.33 . The contrasting result is due to the nature of both measures where AIC is more suitable in determining best predictive model while explaining model by BIC. In female population, both measures point towards $\mathrm{HRb}$ model as best fitted model with value of 11206.70 and 11948.45 , respectively.

In assessing the forecasting performances, MAPE, MAD, and MSE are used. A note to be considered is that the best fit model do not guarantee the best forecasted values. Generally, APC, CBD, and HRa model produce best forecast on crude death rate while CBD, LC, and APC produce best forecast on probability of death. The contradiction might be due to the differences of their function towards model parameter. For female population, however, APC model produce best forecast on both statistics, followed by HRa and RH model. 
Summarizing these three aspects, RH and APC model are suitable in explaining and projecting future mortality. However, APC model is more parsimony with lesser number of parameters, hence APC model is preferred. On the other hand, APC, RH, and HRa model also suitable for female population. Due to APC model's higher accuracy in forecasting, this model is chosen instead of another two.

\section{FORECASTING TAIWANESE MORTALITY FROM 2015 TO 2045}

Since the best model for both genders are APC model, this model is then used to forecast 34 years ahead forward mortality by using full data set. It can be shown that the period index for both gender is estimated to decrease whereby the rate is greater in female population. Cohort index on the other hands shows increment in which male population always dominate across the future cohort. The differences in the period and cohort indices implies that the female population will live longer than male and their gap continue to expand in the far future as shown in Tables 4 and 5. These two tables present estimated probability of death for both genders from year 2015 to 2045 using APC model.

TABLE 4. Estimated probability of death for male population in Taiwan

\begin{tabular}{cccccccc}
\hline Age & 2015 & 2016 & 2017 & $\ldots$ & 2043 & 2044 & 2045 \\
\hline 55 & 0.007737 & 0.007645 & 0.007552 & $\ldots$ & 0.005351 & 0.005279 & 0.005213 \\
$\ldots$ & $\ldots$ & $\ldots$ & $\ldots$ & $\ldots$ & $\ldots$ & $\ldots$ & $\ldots$ \\
65 & 0.015104 & 0.014949 & 0.014836 & $\ldots$ & 0.010630 & 0.010483 & 0.010353 \\
66 & 0.016600 & 0.015952 & 0.015767 & $\ldots$ & 0.011359 & 0.011201 & 0.011063 \\
67 & 0.018354 & 0.018801 & 0.018043 & $\ldots$ & 0.013021 & 0.012840 & 0.012681 \\
68 & 0.019095 & 0.018418 & 0.018842 & $\ldots$ & 0.013224 & 0.013035 & 0.012873 \\
69 & 0.020781 & 0.021757 & 0.020959 & $\ldots$ & 0.015251 & 0.015038 & 0.014845 \\
70 & 0.024311 & 0.022491 & 0.023515 & $\ldots$ & 0.016701 & 0.016470 & 0.016265 \\
71 & 0.025342 & 0.025736 & 0.023778 & $\ldots$ & 0.017879 & 0.017643 & 0.017424 \\
72 & 0.028229 & 0.027616 & 0.028008 & $\ldots$ & 0.019726 & 0.019445 & 0.019216 \\
73 & 0.030075 & 0.030072 & 0.029381 & $\ldots$ & 0.021286 & 0.020970 & 0.020701 \\
74 & 0.033597 & 0.032655 & 0.032609 & $\ldots$ & 0.023394 & 0.023068 & 0.022759 \\
$\ldots$ & $\ldots$ & $\ldots$ & $\ldots$ & $\ldots$ & $\ldots$ & $\ldots$ & $\ldots$ \\
89 & 0.138603 & 0.136063 & 0.134764 & $\ldots$ & 0.095634 & 0.093420 & 0.093945 \\
\hline
\end{tabular}

TABLE 5. Estimated probability of death for female population in Taiwan

\begin{tabular}{cccccccc}
\hline Age & 2015 & 2016 & 2017 & $\ldots$ & 2043 & 2044 & 2045 \\
\hline 55 & 0.003138 & 0.003090 & 0.003024 & $\ldots$ & 0.001818 & 0.001782 & 0.001748 \\
$\ldots$ & $\ldots$ & $\ldots$ & $\ldots$ & $\ldots$ & $\ldots$ & $\ldots$ & $\ldots$ \\
65 & 0.006881 & 0.006902 & 0.006559 & $\ldots$ & 0.003934 & 0.003857 & 0.003780 \\
66 & 0.008811 & 0.008239 & 0.008212 & $\ldots$ & 0.004786 & 0.004692 & 0.004598 \\
67 & 0.009125 & 0.009243 & 0.008589 & $\ldots$ & 0.005099 & 0.005000 & 0.004901 \\
68 & 0.010137 & 0.009877 & 0.009942 & $\ldots$ & 0.005604 & 0.005497 & 0.005389 \\
69 & 0.010713 & 0.010987 & 0.010637 & $\ldots$ & 0.006172 & 0.006049 & 0.005932 \\
70 & 0.012455 & 0.011695 & 0.011918 & $\ldots$ & 0.006839 & 0.006710 & 0.006575 \\
71 & 0.013914 & 0.013762 & 0.012842 & $\ldots$ & 0.00768 & 0.007528 & 0.007383 \\
72 & 0.016277 & 0.016246 & 0.015969 & $\ldots$ & 0.009109 & 0.008936 & 0.008755 \\
73 & 0.016490 & 0.016141 & 0.016010 & $\ldots$ & 0.009176 & 0.008995 & 0.008820 \\
74 & 0.019258 & 0.018638 & 0.018128 & $\ldots$ & 0.010532 & 0.010331 & 0.010124 \\
$\ldots$ & $\ldots$ & $\ldots$ & $\ldots$ & $\ldots$ & $\ldots$ & $\ldots$ & $\ldots$ \\
89 & 0.114931 & 0.112048 & 0.109303 & $\ldots$ & 0.058732 & 0.058222 & 0.055863 \\
\hline
\end{tabular}


ASSESSING SOLVENCY RISK DUE TO DIFFERENT MORTALITY MODEL ASSUMPTIONS

Since APC model best suited to both genders population, there is a risk arises when the annuity portfolio is priced under other mortality models. We consider eight portfolios with different compositions as shown in Table 6 . The number of annuitans for each portfolios is fixed at 10000

TABLE 6. The compositions of annuitans for the portfolios

\begin{tabular}{lcccc}
\hline \multirow{2}{*}{ Portfolio } & \multicolumn{2}{c}{ Male } & \multicolumn{2}{c}{ Female } \\
\cline { 2 - 5 } & Age 60 & Age 65 60 & Age 65 \\
\hline 1 & 0 & 5000 & 0 & 5000 \\
2 & 0 & 7500 & 0 & 2500 \\
3 & 0 & 2500 & 0 & 7500 \\
4 & 2500 & 2500 & 2500 \\
5 & 1250 & 3750 & 1250 & 3750 \\
6 & 3750 & 1250 & 3750 & 1250 \\
7 & 1250 & 3750 & 3750 & 1250 \\
8 & 3750 & 1250 & 1250 & 3750 \\
\hline
\end{tabular}

Based on Table 7, the result shows that portfolio priced under HRa and $\mathrm{HRb}$ model possess greatest risk with greatest severity of NT\$ 13561.61 in the case of equal gender proportion. When the male proportion increases, risk brought by the LC and CBD models decreases but increases for RH model case. The increment in the number of female annuitant bring large risk to portfolio priced under the LC and CBD models as the risk almost doubled. In all cases, portfolio under the $\mathrm{RH}$ model generally produce the least risk and suffer least severity.

TABLE 7. Probability of ruin and severity due to different underlying mortality model estimate

\begin{tabular}{|c|c|c|c|c|c|c|c|}
\hline Portfolio & Mortality Model & $\mathrm{LC}$ & RH & APC & CBD & $\mathrm{HRa}$ & $\mathrm{HRb}$ \\
\hline \multirow[b]{2}{*}{ Portfolio 1} & Probability of ruin & 0.2004 & 0.0024 & 0.5086 & 0.3772 & 1.0000 & 1.0000 \\
\hline & $\begin{array}{l}\text { Present value of } \\
\text { severity }\end{array}$ & 486.30 & 423.61 & 715.32 & 630.96 & 7385.54 & 13561.61 \\
\hline \multirow[b]{2}{*}{ Portfolio 2} & Probability of ruin & 0.0660 & 0.0154 & 0.5040 & 0.1684 & 1.0000 & 1.0000 \\
\hline & $\begin{array}{l}\text { Present value of } \\
\text { severity }\end{array}$ & 525.35 & 385.48 & 873.58 & 570.80 & 8462.93 & 13449.65 \\
\hline \multirow[b]{2}{*}{ Portfolio 3} & Probability of ruin & 0.5358 & 0.0004 & 0.5080 & 0.7282 & 1.0000 & 1.0000 \\
\hline & $\begin{array}{l}\text { Present value of } \\
\text { severity }\end{array}$ & 683.96 & 334.26 & 663.12 & 885.44 & 6301.56 & 13666.97 \\
\hline
\end{tabular}




\begin{tabular}{|c|c|c|c|c|c|c|c|}
\hline & Probability of ruin & 0.0000 & 0.0000 & 0.0000 & 0.0000 & 0.0026 & 0.9762 \\
\hline Portfolio 4 & $\begin{array}{l}\text { Present value of } \\
\text { severity }\end{array}$ & 0.00 & 0.00 & 0.00 & 0.00 & 391.52 & 2308.66 \\
\hline \multirow[b]{2}{*}{ Portfolio 5} & Probability of ruin & 0.0000 & 0.0000 & 0.0000 & 0.0000 & 0.9812 & 1.0000 \\
\hline & $\begin{array}{l}\text { Present value of } \\
\text { severity }\end{array}$ & 0.00 & 0.00 & 0.00 & 0.00 & 2199.70 & 7903.52 \\
\hline & Probability of ruin & 0.0000 & 0.0000 & 0.0000 & 0.0000 & 0.0000 & 0.0024 \\
\hline Portfolio 6 & $\begin{array}{l}\text { Present value of } \\
\text { severity }\end{array}$ & 0.00 & 0.00 & 0.00 & 0.00 & 0.00 & 294.68 \\
\hline \multirow{2}{*}{ Portfolio 7} & Probability of ruin & 0.0000 & 0.0000 & 0.0000 & 0.0000 & 0.0000 & 0.6510 \\
\hline & $\begin{array}{l}\text { Present value of } \\
\text { severity }\end{array}$ & 0.00 & 0.00 & 0.00 & 0.00 & 0.00 & 1184.79 \\
\hline \multirow[b]{2}{*}{ Portfolio 8} & Probability of ruin & 0.0000 & 0.0000 & 0.0000 & 0.0000 & 0.0452 & 0.9998 \\
\hline & $\begin{array}{l}\text { Present value of } \\
\text { severity }\end{array}$ & 0.00 & 0.00 & 0.00 & 0.00 & 403.78 & 4007.00 \\
\hline
\end{tabular}

When the portfolio includes annuitant aged 60 as found in portfolios 4-8, the risk disapppears abruptly for cases of LC, RH, APC, and CBD model. The change in proportion of annuitant aged 60 do not affect solvency risk on portfolio under M6 and M7 model implies that population age 60 is not the source of risk. Referring to Portfolio 5, when the proportion of female annuitant age 65 increase while held fixed for both gender annuitant age 60 , the solvency risk increase from 0.0000 to 0.9812 in M6 model. Meanwhile comparing between portfolios 5 and 7, in which Portfolio 5 has higher proportion of females age 65 , the probability of ruin increases from 0.6510 in Portfolio 7 to 1.0000 in Portfolio 5 for the M7 model. This shows that in these four populations from different age group and gender, female aged 65 brings greatest solvency risk to portfolio priced under all models.

\section{CONCLUSION}

In a nutshell, inclusion of various uncertainties is effective in improving accuracy of point estimate but do not work well in interval estimate. This is because the interval width under simulation technique do not appear significantly smaller except for M7 model forecast on female high age population. Secondly, APC model is the best model explaining and projecting future mortality in Taiwan population after considering the ability to produce biological plausible rate, goodness of fit and forecasting performance. Besides, gap between male and female lifespan is expected to widen in far future. Lastly, solvency risk is the greatest in portfolio which contains high proportion of female age 65 .

\section{ACKNOWLEDGEMENTS}

The authors would like to thank Universiti Kebangsaan Malaysia for sponsoring this study through the grant GUP-2018-110.

\section{REFERENCES}

Brouhns, N., Denuit, M. \& Vermunt, J.K. 2002. A poisson logbilinear regression approach to the construction of projected lifetables. Insurance: Mathematics and Economics 31(3): 373-393.

Cairns, A.J., Blake, D., Dowd, K., Coughlan, G.D., Epstein, D., Ong, A. \& Balevich, I. 2009. A quantitative comparison of stochastic mortality models using data from England and Wales and the United States. North American Actuarial Journal 13(1): 1-35.

Cairns, A.J.G., Blake, D. \& Dowd, K. 2006. A Two-factor model for stochastic mortality with parameter uncertainty: Theory and calibration. Journal of Risk and Insurance 73(4): 687718.

Dushi, I., Friedberg, L. \& Webb, T. 2010. The impact of aggregate mortality risk on defined benefit pension plans. Journal of Pension Economics and Finance 9(4): 481-503.'

Haberman, S. \& Renshaw, A. 2011. A comparative study of parametric mortality projection models. Insurance: Mathematics and Economics 48(1): 35-55. 
Lee, R.D. \& Carter, L.R. 1992. Modeling and forecasting U.S. mortality. Journal of the American Statistical Association 87(419): 659-671.

Nor, S.R.M., Yusof, F. \& Bahar, A. 2018. Multi-population mortality model: A practical approach. Sains Malaysiana 47(6): 1337-1347.

Renshaw, A.E. \& Haberman, S. 2006. A cohort-based extension to the Lee-Carter model for mortality reduction factors. Insurance: Mathematics and Economics 38(3): 556-570.

Villegas, A., Kaishev, V.K. \& Millossovich, P. 2015. StMoMo: An R package for stochastic mortality modelling. In 7 th Australasian Actuarial Education and Research Symposium.

Yang, S., Yue, J.C. \& Hong-Chih, H. 2010. Modeling longevity risks using a principal component approach: A comparison with existing stochastic mortality models. Insurance: Mathematics and Economics 46(1): 254-270.
Zamzuri, Z.H., Sapuan, M.S. \& Ibrahim, K. 2018. The extra zeros in traffic accident data: A study on the mixture of discrete distributions. Sains Malaysiana 47(8): 1931-1940.

Department of Mathematical Sciences

Faculty of Science and Technology

Universiti Kebangsaan Malaysia

43600 UKM Bangi, Selangor Darul Ehsan

Malaysia

*Corresponding author; email: zamira@ukm.edu.my

Received: 9 October 2019

Accepted: 16 April 2020 